\title{
Study on Reuse Strategy of Abandoned Industrial Square - in the case of Jingxi Wang Ping Coal Mine
}

\author{
Xiaodan $\mathrm{Li}^{1}{ }^{1}$, , Zhiting Chen ${ }^{1}$, Lijun $\mathrm{Jia}^{1}$, Wei $\mathrm{Wu}^{1}$, Hailiang Zhang ${ }^{1}$, Tianyi $\mathrm{Ma}^{1}$, Tao Wang ${ }^{1}$ \\ School of Mechanics and Civil Engineering, China University of Mining and Technology, Beijing100083, China.
}

\begin{abstract}
Wangping Coal Mine, whose industrial heritage is of great value, was one of the eight coal mines in Beijing. A large number of field surveys and analysis of the abandoned industrial facilities of Wangping Coal Mine were carried out in this paper. From the perspective of protecting industrial heritage culture and sustainable development, this paper studies the ideas and strategies for reusing the abandoned facilities of the Wangping Coal Mine. In order to protect its industrial heritage as much as possible, it is suggested to reuse the industrial square of Wangping Coal Mine as a community park.
\end{abstract}

\section{Introduction}

According to the instructions of Responsibility Document for Resolving Overcapacity in the Coal Industry to Realize the Goal of Relief from Difficulty, Wangping Coal Mine was asked to stop its production on August 16th, 2016. It was formally established in 1964 and suspended at the beginning of 1994. With 30 years of mining history, it has made outstanding contributions to the development of the coal industry of Beijing[1].

\section{Overview of Wangping Coal Mine}

\subsection{Geographic location}

Wangping Coal Mine is located in Wangping Town, which is in the west of Mentougou District in Beijing. The railway from Yongding Gate to Muchengjian passes through it. 109 National Road runs to the east of it. Tanwang Road passes through the middle of it (Fig. 2-1). The whole mining area is steep, because its north, west and south are surrounded by mountains.

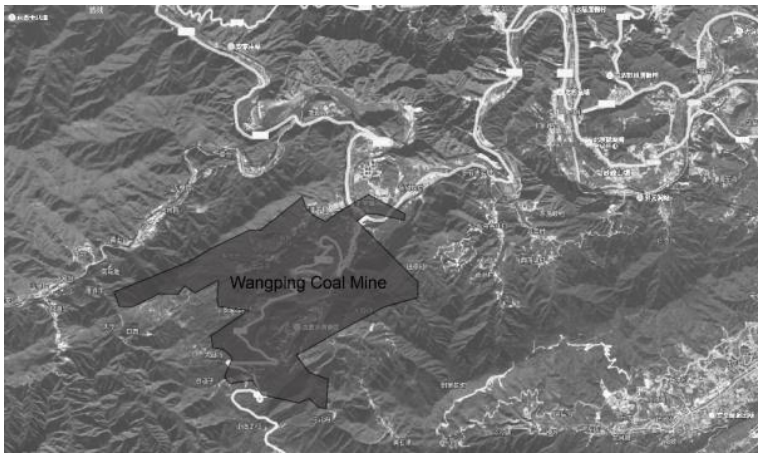

Fig.2-1 Location map of Wangping Coal Mine.

\subsection{Historical evolution}

Wangping Coal Mine has a long history (Table 2-1) and was one of the eight coal mines of Jingxi Mining Bureau[2].

Table 2-1 History of Wangping Coal Mine.

\begin{tabular}{|c|l|}
\hline Age & \multicolumn{1}{|c|}{ Historical events } \\
\hline 1919 & $\begin{array}{l}\text { Huazhao Wen opened Anjiatan Coal Mine around } \\
\text { Anjiatan and Wangping. It was the predecessor of } \\
\text { Wangping Coal Mine. }\end{array}$ \\
\hline 1951 & $\begin{array}{l}\text { The Beijing Public Security Bureau took over } \\
\text { Yugong Mine and Shengli Mine and established } \\
\text { Qinghe Mine in Anjiatan Village. }\end{array}$ \\
\hline 1953 & $\begin{array}{l}\text { In April, the local government took over Tongfeng } \\
\text { Coal Mine in Anjiatan Village and all the } \\
\text { surrounding coal mines. }\end{array}$ \\
\hline 1954 & $\begin{array}{l}\text { In March, Jingxi Mining Bureau took over them and } \\
\text { established Anjiatan Coal Mine. }\end{array}$ \\
\hline 1958 & $\begin{array}{l}\text { In May, construction of Wangping shaft was started. } \\
\text { In August, Jingxi Mining Bureau decided to build } \\
\text { Huapogen footrill. }\end{array}$ \\
\hline
\end{tabular}

\footnotetext{
* Corresponding author: tjulxd@sina.com
} 


\begin{tabular}{|c|l|}
\hline 1960 & In April, Wangping shaft was put into operation. \\
\hline 1964 & In March, Wangping Coal Mine was established. \\
\hline 1977 & $\begin{array}{l}\text { Wangping Coal Mine absorbed Dajiao Mine, which } \\
\text { was part of Mentougou Coal Mine. In August, } \\
\text { Jiulong footrill was started to be built. }\end{array}$ \\
\hline 1994 & $\begin{array}{l}\text { The production of Wangping Coal Mine was } \\
\text { suspended. } \\
\text { Prior to that, its annual output was } 800,000 \text { tons. }\end{array}$ \\
\hline
\end{tabular}

\subsection{Small coal kilns}

Before the foundation of New China, besides Tongfeng Coal Mine, there were five or six small coal kilns around Wangping Village. In 1951, Tongxian Military District, the Public Security Bureau of Beijing Municipal Public Security Bureau, and the National Coal Mine Trade Union and other units have successively established 16 small coal kilns in Anjiatan Village. In April 1953, The local government took over Tongfeng Coal Mine and all the surrounding small coal kilns [3].

Most of the small coal kilns in Wangping Coal Mine were located in Lujiapo, Jiaoling and Anjiatan. According to the government requirements, they were shut down successively in 2000, 2001 and 2009. Except for the comprehensive information on he small coal kilns closed in 2009, the data on that closed in 2000 and 2001 were barely preserved. (Table 2-2)

Table 2-2 List of closed coal kilns in Wangping Coal Mine, 2000-2009.

\begin{tabular}{|c|c|}
\hline Age & List of closed coal kilns \\
\hline 2000 & $\begin{array}{l}\text { Xiwangping Coal Mine, Yumin Coal Mine, } \\
\text { Huangqugou Coal Mine, Pingjiu Coal Mine, } \\
\text { Houling Coal Mine, Menlingkou Coal Mine, } \\
\text { Daqiao Coal Mine, Fuxing Coal Mine }\end{array}$ \\
\hline 2001 & $\begin{array}{l}\text { Dongwangping Coal Mine, Baoshun Coal Mine, } \\
\text { Jiuyuan Coal Mine, Xingwang Coal Mine, } \\
\text { Huanggang Coal Mine, Dongshan Coal Mine, } \\
\text { Guacaodi Coal Mine, Shizidao Coal Mine, } \\
\text { Wanda Coal Mine, Shanlindaxin Coal Mine }\end{array}$ \\
\hline 2009 & $\begin{array}{l}\text { Magezhuang Coal Mine (1), Nanjian Coal Mine } \\
\text { (2), Ximage Coal Mine (3), Chunan Coal Mine } \\
\text { (4), Jiaoling Xingda Coal Mine (5), Pingxi } \\
\text { Coal Mine (6), Yunfutong Coal Mine ( } 7) \text {, } \\
\text { Nanwayao Coal Mine in Bai Daozi ( } 8 \text { ), Pingdong } \\
\text { Coal Mine( 9), Daqugou Coal Mine (10), Xinkou } \\
\text { Coal Mine in Zhuanyaogou (11), Longshan Coal } \\
\text { Mine (12), Changhong Coal Mine in Baidaozi } \\
\text { (13), Suwa Coal Mine (14), Houtouyuan Coal } \\
\text { Mine (15), Jinxiu Coal Mine (16), Jinyu Coal } \\
\text { Mine (17), Qingtou Coal Mine (18), Shunmin } \\
\text { Coal Mine in Bei Ling (19), Dongkou Coal Mine } \\
\text { of Dahua (20), Zhaojiatai Coal Mine (21), } \\
\text { Tanzhesi Coal Mine (22) (As shown on the right } \\
\text { Fig.). }\end{array}$ \\
\hline
\end{tabular}

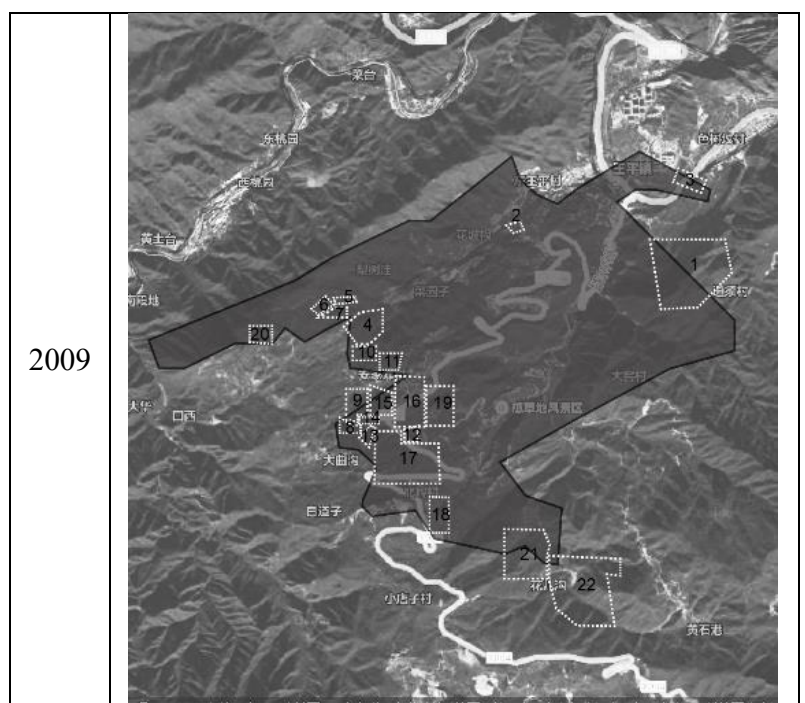

\section{Security situation}

\subsection{Goafs and collapse sites}

Most of the goafs in Wangping Coal Mine were located in the west and south of Anjiatan, Nanling, Beiling, Liujiafen, Shizidao and other villages. They covered about $2 \mathrm{~km}^{2}$.

In August 2016, there were five small collapse pits on the hillside of wasteland in the west of Anjiatan. Based on many investigations and evaluations of the current geological environment of Wangping Coal Mine, the development of small collapse pits has been basically stable. [4] Under the current conditions, the mine geological environment has slight impacts on the human settlements and the environment around[5,6].

\subsection{Groundwater}

Related research showed that after the shutdown of Wangping coal mine, the groundwater level has picked up. The content and saturation of original water has been restored. The underground water in the mining area has no toxic or harmful substances and can be exploited and utilized $[7,8]$.

\section{Protective reuse strategy}

It is found that the production equipments, office buildings, dormitory buildings, railroad tracks and others of Wangping Coal Mine industrial square are well preserved (Fig. 4-1). They are very valuable industrial heritage buildings. 


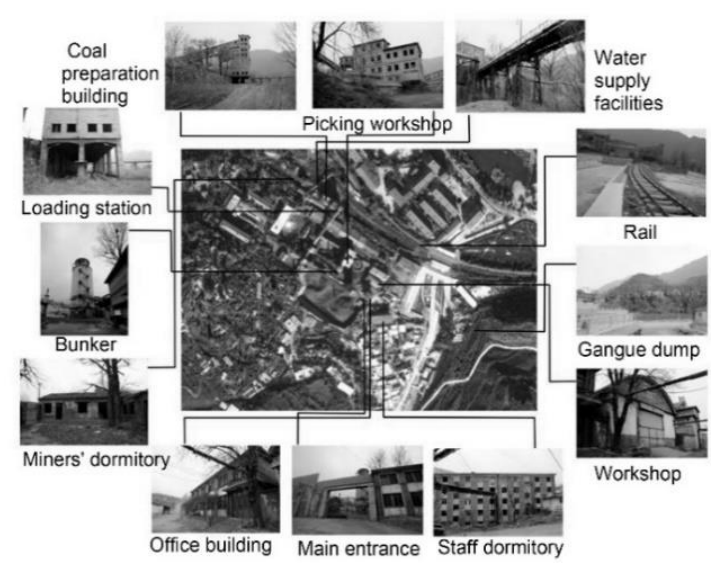

Fig.4-1 Current situation of industrial square facilities

\subsection{Reuse principle}

In order to take good use of the original appearance of the industrial square, it is suggested to take some reinforcement measures. And buildings that have nothing to save should be demolished, and some coal-industrystyle facilities should be reserved.

\subsection{Reuse strategy}

Furthermore, the needs of local residents and urban tourists should be taken into account. Therefore, the industrial square of Wangping Coal Mine is suggested to be reused as a community park [9]. It consists of Pedestrian street, Industrial heritage park, Civic activity center, Railway park, Ecological experiment base

( Fig.4-2 ). This strategy creates more room for interaction and outdoor activities for people. The commercial pedestrian street at the entrance has promoted local economic development which also satisfies residents' shopping needs.

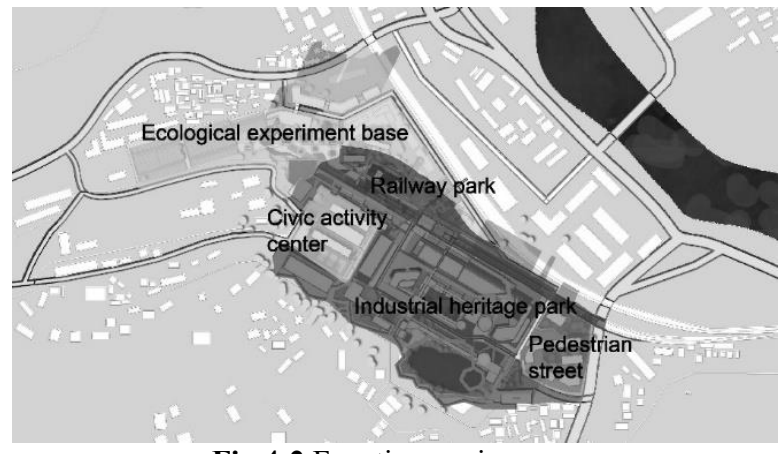

Fig.4-2 Function zoning map

The part of the coal mine ecological park includes the ring path system and the industrial park system. The design of the ring path, which allows visitors to overlook the Wangping Coal Mine, was inspired by the Acropolis' tour and the New York High Line Park. The design of the industrial park is based on the successful experience of the German Ruhr area.

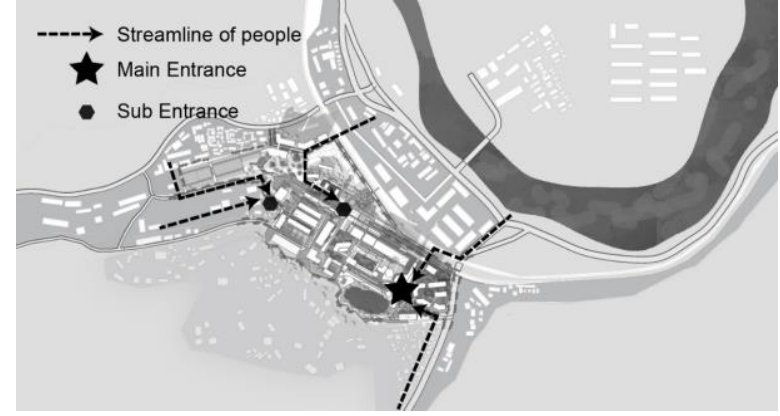

Fig.4-2 Streamline analysis diagram

Because of its high degree of advantage, the coal bunker has become a landmark of the entire mining area. It was reused as a watchtower connected to the circular path system. The Waterscape Park under the observation tower was transformed from the original collapsing pit, which echoes the northern wetland of Wangping Town.

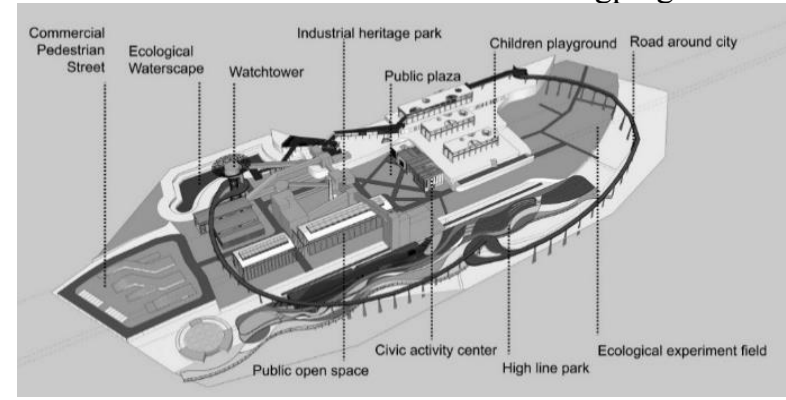

Fig. 4-3 Aerial view

\section{Conclusion}

Wangping Coal Mine have witnessed the profound impact of mining activities on Beijing. Its reuse is a respect for the history of cities and the culture of coal mines. At the same time it helps to enhance the local residents' sense of identity and social belonging. This study explores the reuse strategy of Wangping Coal Mine Industrial square and hopes to promote the reusing and sustainable development of Jingxi Coal Mine.

\section{Acknowledgements}

Thanks to Beijing Coal Group for providing a lot of information for this study. I would also like to thank my project assistants Lijun Jia and Wei WU, the anonymous reviewers and the Editor.

\section{References}

1. Li X, Yang H, Chen Z, et al. Evaluation system for prioritization tool to redevelop abandoned coal mine industry square based on DSR model.TCSAE, 34,224(2018)

2. Closed Mine Report of Wangping Coal Mine, Beijing Jingmei Group Co., Ltd.

3. Liu Y, Sun X, Li J, et al. Restoration Effect Analysis of Abandoned Coal Mine Engineering of Mentougou in Beijing Based on Soil Physicochemical Properties. Chin. Sci. Bull.,28,246(2012) 
4. Zhang H. Study on the Environmental management of Mentoukou Village Coal Mine in the Mentoukou District of Beijing. Urban Geology, 6,54(2011)

5. Yan-Jun WU, Gen-Yi LI, et al. Analysis About Influence Factors and Collapse Disaster Characteristics of Small Coalmine Gob Areas in the West of Beijing Mountain Area. Journal of Geological Hazards \& Environment Preservation, 28,46(2017)

6. Cheng X Q, Zhao F Y. Quantitative classification and ordination of natural vegetation on abandoned mine land in Mentougou District, Beijing. J. Northeast For. Univ. (Chin. Ed.), 38,71(2010)

7. LONG Jinghua, HU Zhenqi. Field Investigation and Reutilization Evaluation of Abandoned Mine Land in Mentougou District of Beijing.Coal Engineering, 47,120(2015)

8. Zhang L, Zhang S, Huang Y, et al. Exploring an Ecologically Sustainable Scheme for Landscape Restoration of Abandoned Mine Land: ScenarioBased Simulation Integrated Linear Programming and CLUE-S Model. Int. J. Environ. Res. Public Health, 13,354(2016)

9. Yi X. Problems and Redevelopment Strategy for Old Industrial Area. Building Resilient Cities in China: The Nexus between Planning and Science. Springer International Publishing, 2015:349-361. 